\title{
Multi-Drug Resistant Bacterial Strains in Lower Respiratory Tract Infections, Antibiotic Sensitivity Patterns and Risk Factors
}

\author{
Jatan B. Sherchan ${ }^{1}$, Pranita Gurung ${ }^{2}$, Dirgh Singh Bam ${ }^{3}$ and Jeevan Bahadur Sherchand ${ }^{4}$ \\ ${ }^{1}$ Department of Medical Microbiology \\ Kathmandu University, School of Medical Sciences, Dhulikhel \\ ${ }^{2}$ Kathmandu Medical College \\ Sinamangal, Kathmandu \\ ${ }^{3}$ Dirgh-Jeevan Health Care and Research Centre \\ Tripureswar, Kathmandu \\ ${ }^{4}$ Public Health Research Laboratory and Microbiology \\ Tribhuvan University Institute of Medicine, Kathmandu \\ e-mail: jatansherchan@gmail.com
}

\begin{abstract}
Isolation of multidrug resistant bacteria such as extended spectrum beta-lactamase (ESBL), metallo beta-lactamase (MBL) producing and Methicillin resistant Staphylococcus aureus (MRSA) causing lower respiratory tract infection (LRTI) is associated with various risk factors and a major challenge in treatment. So, the study determined bacterial etiology of lower respiratory tract infection and antibiotic sensitivity pattern with special reference to ESBL, MBL, and MRSA strains along with risk factors associated with such strains. A total of 120 specimens were collected from patients with lower respiratory tract infection along with clinical details. Combination disk method was done for the detection of ESBL and MBL producing isolates and oxacillin disc was used to detect MRSA. Out of 120 specimens, $87.5 \%$ was monomicrobial while $12.5 \%$ was polymicrobial infection. Pseudomonas aeruginosa (36.19\%) was the predominant followed by Acinetobacter baumannii (28.57\%), Klebsiella pneumoniae (20.95\%), Escherichia coli (8.57\%) and Staphylococcus aureus (5.72\%). Total 33 (31.43\%) out of 105 monomicrobial isolate were MDR. All MDR E. coli, K. pneumoniae, P. aeruginosa were ESBL producers and (6, 20\%) out of total A. baumannii isolated produced MBL and was not found to produce ESBL. All MDR S. aureus isolates were found to be resistant to methicillin. Carbapenems followed by amikacin were found to be the most effective antibiotic for Gram negative bacilli causing LRTI. Vancomycin, Teicoplanin \& Linezolid were found to be the most effective antibiotics for MRSA. 28 out of 33 MDR isolate possessing patients had comorbid illness. Isolation of MRSA, ESBL and MBL producing bacteria in LRTI are increasing in number. Increased prevalence of MDR bacterial strains form patients with comorbid illness is a major problem in healthcare centers.
\end{abstract}

Key words: MDR, LRTI, ESBL, MBL, MRSA

\section{Introduction}

Treatment of patients from whom multidrug resistant bacteria has been isolated is becoming a major challenge to the physicians these days. Extended spectrum beta-lactamase (ESBL), metallo betalactamase (MBL) and Methicillin resistant Staphylococcus aureus (MRSA) producing bacterial strains are common ones. These bacterial isolates causing LRTI is associated with risk factors and has modified therapeutic approach. Risk factors such immunocompromised status may be a major factor which is responsible for some of the cases of MDR bacterial respiratory infections. Antibiotic is the mainstay of therapy for bacterial infections but they have been misused and overused. Hence, bacteria gained resistance to the antibiotics. Therefore the treatment of risk factors and avoiding misuse of antibiotics are important for infection control. 
Almost three quarters of all antibiotic consumptions are for respiratory tract infections (File 2000). Beta lactams are used for large number of bacterial infections, but their efficacy has been decreasing because of acquired resistance among pathogenic bacteria (Rossolini 2005). The exposure of bacterial strains to a multitude of â-lactams has induced a dynamic and continuous production and mutation of â-lactamase in many bacteria, expanding their activity even against later generation cephalosporins and carbapenems by the production of ESBL and MBL respectively (Araj 2003). Since the genes that code for the production of ESBL are often linked to other resistance genes causing extended spectrum of drug resistance, this will result into fewer therapeutic alternatives (Clinical \& Laboratory Standards Institute 2007).

According to Clinical and Laboratory Standards Institute once an ESBL producing strain is detected, the lab should report it as resistant to all penicillins, cephalosporins and monobactam, even if they test as susceptible in vitro (Araj 2003). MBL represent a formidable challenge to antimicrobial chemotherapy due to their extremely broad substrate specificity and uniqueness: most â-lactams (including carbapenems and extended spectrum cephalosporin) are efficiently degraded by these enzymes, while conventional âlactamase inactivators such as clavulanate, sulbactam and tazobactams, and are useless against them (Araj 2003). Ineffectiveness of carbapenems due to the production of MBL is of great concern for the management of severe infections and the importance of identification of such resistance strains to prevent their dissemination. The resistance mechanisms like ESBL and MBL are already disseminating on a worldwide scale. In recent years MBL genes have spread from P. aeruginosa to Enterobacteriaceae and a clinical scenario appears to be developing that could simulate the global spread of ESBLs. In Nepal, due to the lack of antibiotic policies and comorbid risk factors, MDR organisms are increasing.

\section{Methodology}

120 lower respiratory tract samples; sputum was collected between June 2011 and December 2011 in Dirgh Jeevan Health Care and Research Centre, Tripureswar. The antibiotic sensitivity tests of the pathogens isolated from the clinical specimen against different antibiotics were done using Mueller Hinton agar by the standard disk diffusion technique of KirbyBauer method as recommended by CLSI.

Screening test for the production of ESBL was performed by using ceftazidime (CAZ) (30mg) and cefotaxime (CTX) (30mg) disks. If the zone of inhibition was between d" $22 \mathrm{~mm}$ for ceftazidime and between d" $27 \mathrm{~mm}$ for cefotaxime, the isolate was considered as a potential ESBL producer as recommended by CLSI (Clinical and Laboratory Standards Institute 2007).

The confirmations of ESBL were done by Combination disk method in which CAZ and CTX alone and in combination with clavulanic acid (CA) (10ìg) were used. An increase ZOI of e" $5 \mathrm{~mm}$ for either antimicrobial agent in combination with CA versus its zone when tested alone confirmed ESBL (Clinical and Laboratory Standards Institute 2007). E. coli ATCC 25922 and K. pneumoniae ATCC 700603 were used as negative controls respectively.

Screening for MBL detection was done for the isolates which were resistant to imipenem (IPM) and meropenem (MEM) .Confirmation was done by combination disk method where two IPM disks (10ìg) , one containing 10 ìl of $0.1 \mathrm{M}$ (292 ìg) anhydrous EDTA, were placed $25 \mathrm{~mm}$ apart centre to centre. An increase in zone diameter of $>4 \mathrm{~mm}$ around the IMPEDTA disk compared to that of the IPM disk alone was considered positive for MBL. For detection of MRSA recommendation of CLSI was followed in which agar plate containing $6 \mu \mathrm{g} / \mathrm{ml}$ of oxacillin and MüellerHinton agar supplemented with $\mathrm{NaCl}(4 \% \mathrm{w} / \mathrm{v} ; 0.68 \mathrm{~mol} /$ $\mathrm{L}$ ) was used in which if growth was detected than it was considered to be MRSA.

For MBL test standardization, P. aeruginosa ATCC 27853 and P.aeruginosa PA 105663 were used as negative and positive controls respectively. Clinical histories of the patients were collected in separate questionnaires.

\section{Results and Discussion}

Out of total 120 specimens, $87.5 \%$ (105) was monomicrobial while $12.5 \%$ (15) was polymicrobial infection. 94.28\% was Gram negative bacteria while $5.72 \%$ was Gram positive bacteria. P. aeruginosa (38, 36.19\%) was the predominant pathogen followed by $A$. baumannii (30, 28.57\%), K. pneumoniae (22, 20.95\%), E. coli $(9,8.57 \%)$ and S. aureus $(6,5.72 \%)$ as shown in figure 1. Among which $(14,36.84 \%)$ of $P$. aeruginosa, $(8,26.66 \%)$ of A. baumannii, $(5,22.72 \%)$ of .K. 


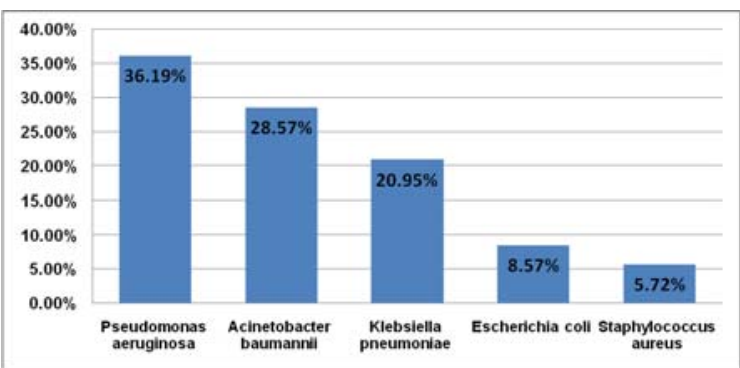

Fig. 1. Organism isolated from the patients

pneumoniae, (3, 33.33\%) of E. coli and (3, 50\%) of $S$. aureus, were found to be MDR. Hence total 33 (31.43\%) out of 105 monomicrobial isolate were MDR as shown in figure 2. All MDR E. coli, Klebsiella spp., Pseudomonas were ESBL producers, (6, 20\%).

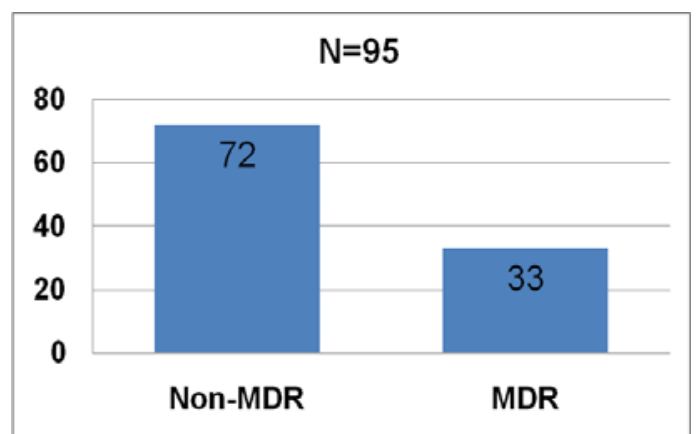

Fig. 2. Multidrug resistant and non-multidrug resistant strains

Out of total A. baumannii isolated (6, 20\%) produced MBL, but not found to produce ESBL in the study. All MDR S. aureus isolates were found to be resistant to methicillin.

Table 1. Antibiotic sensitivity pattern of Staphylococcus aureus

\begin{tabular}{|c|c|c|c|}
\hline ANTIBIOTICS & & $\begin{array}{c}\text { MSSA } \\
\mathbf{N}=3\end{array}$ & $\begin{array}{c}\text { MRSA } \\
\mathbf{N}=3\end{array}$ \\
\hline Amoxicillin & $\begin{array}{l}\text { Sensitive } \\
\text { Resistant }\end{array}$ & $\begin{array}{l}2(66.7 \%) \\
1(33.3 \%)\end{array}$ & $\begin{array}{l}0(0 \%) \\
3(100 \%)\end{array}$ \\
\hline 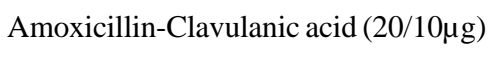 & $\begin{array}{l}\text { Sensitive } \\
\text { Resistant }\end{array}$ & $\begin{array}{l}3(100 \%) \\
0(0 \%)\end{array}$ & $\begin{array}{l}0(0 \%) \\
3(100 \%)\end{array}$ \\
\hline Erythromycin $(15 \mu \mathrm{g})$ & $\begin{array}{l}\text { Sensitive } \\
\text { Resistgant }\end{array}$ & $\begin{array}{l}2(66.66 \%) \\
1(33.33 \%)\end{array}$ & $\begin{array}{l}0(0 \%) \\
3(100 \%)\end{array}$ \\
\hline Oxacillin $(1 \mu \mathrm{g})$ & $\begin{array}{l}\text { Sensitive } \\
\text { Resistant }\end{array}$ & $\begin{array}{l}3(100 \%) \\
0(0 \%)\end{array}$ & $\begin{array}{l}0(0 \%) \\
3(100 \%)\end{array}$ \\
\hline Gentamicin $(10 \mu g)$ & $\begin{array}{l}\text { Sensitive } \\
\text { Resistant }\end{array}$ & $\begin{array}{l}2(66.66 \%) \\
1(33.33 \%)\end{array}$ & $\begin{array}{l}1(33.33 \%) \\
2(66.66 \%)\end{array}$ \\
\hline Ciprofloxacin $(5 \mu \mathrm{g})$ & $\begin{array}{l}\text { Sensitive } \\
\text { Resistant }\end{array}$ & $\begin{array}{l}0(0 \%) \\
3(100 \%)\end{array}$ & $\begin{array}{l}0(0 \%) \\
3(100 \%)\end{array}$ \\
\hline 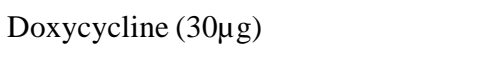 & $\begin{array}{l}\text { Sensitive } \\
\text { Resistant }\end{array}$ & $\begin{array}{l}3(100 \%) \\
0(0 \%)\end{array}$ & $\begin{array}{l}2(66.66 \%) \\
1(33.33 \%)\end{array}$ \\
\hline Cotrimoxazole $(1.25 / 23.75 \mu \mathrm{g})$ & $\begin{array}{l}\text { Sensitive } \\
\text { Resistant }\end{array}$ & $\begin{array}{l}3(100 \%) \\
0(0 \%)\end{array}$ & $\begin{array}{l}2(66.66 \%) \\
1(33.33 \%)\end{array}$ \\
\hline Chloramphenicol $(30 \mu \mathrm{g})$ & $\begin{array}{l}\text { Sensitive } \\
\text { Resistant }\end{array}$ & $\begin{array}{l}3(100 \%) \\
0(0 \%)\end{array}$ & $\begin{array}{l}2(66.66 \%) \\
1(33.33 \%)\end{array}$ \\
\hline Amikacin $(30 \mu \mathrm{g})$ & $\begin{array}{l}\text { Sensitive } \\
\text { Resistant }\end{array}$ & $\begin{array}{l}2(66.66 \%) \\
1(33.33 \%)\end{array}$ & $\begin{array}{l}1(33.33 \%) \\
2(66.66 \%)\end{array}$ \\
\hline Clindamycin $(2 \mu \mathrm{g})$ & $\begin{array}{l}\text { Sensitive } \\
\text { Resistant }\end{array}$ & $\begin{array}{l}3(100 \%) \\
0(0 \%)\end{array}$ & $\begin{array}{l}2(66.66 \%) \\
1(33.33 \%)\end{array}$ \\
\hline Linezolid $(30 \mu \mathrm{g})$ & $\begin{array}{l}\text { Sensitive } \\
\text { Resistant }\end{array}$ & $\begin{array}{l}3(100 \%) \\
0(0 \%)\end{array}$ & $\begin{array}{l}3(100 \%) \\
0(0 \%)\end{array}$ \\
\hline Vancomycin $(30 \mu g)$ & $\begin{array}{l}\text { Sensitive } \\
\text { Resistant }\end{array}$ & $\begin{array}{l}3(100 \%) \\
0(0 \%)\end{array}$ & $\begin{array}{l}3(100 \%) \\
0(0 \%)\end{array}$ \\
\hline Teicoplanin $(30 \mu \mathrm{g})$ & $\begin{array}{l}\text { Sensitive } \\
\text { Resistant }\end{array}$ & $\begin{array}{l}3(100 \%) \\
0(0 \%)\end{array}$ & $\begin{array}{l}3(100 \%) \\
0(0 \%)\end{array}$ \\
\hline
\end{tabular}


Carbapenems, Cefepime and amikacin were found to be the most effective antibiotic for Gram negative bacilli causing LRTI except MDR A. baumanni which produced metallo-betalactamase. Vancomycin, Teicoplanin \& Linezolid were found to be the most effective for MRSA.

Out of total 33 MDR bacterial possessing patients 10 people were diabetic, 8 patients' age was over 75 years, 5 had malignancy, and 5 patients had renal impairment. Hence 28 out of 33 MDR isolate possessing patients had comorbid illness i.e. $84.8 \%$ of MDR isolate possessing patients had comorbid illness which might

\section{Antibiotic sensitivity pattern of Pseudomonas aeruginosa:}

All $P$. aeruginosa isolated were sensitive to Meropenem followed by $84.21 \%$ sensitive to Amikacin as depicted in table 2. be the risk factors as shown in figure 3 .

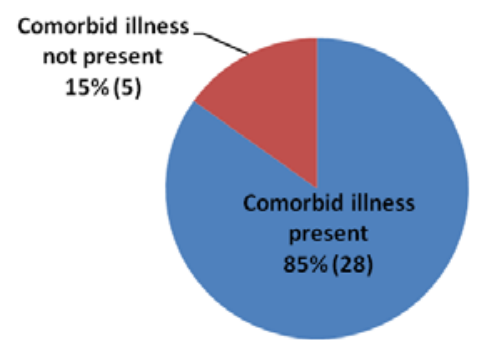

Fig. 3. Comorbid illness and risk factor present in MDR isolated patients

Antibiotic sensitivity pattern of $E$. coli, K. pneumonia and A. baumanni: Meropenem and cefepime were most effective for MDR E. coli and $K$. pneumonia. Amikacin was most effective for MDR A. baumannia as shown in table 3 .

Table 2. Antibiotic sensitivity pattern of Pseudomonas aeruginosa

\begin{tabular}{|c|c|c|}
\hline ANTIBIOTICS & & $\mathbf{N}=38$ \\
\hline Ceftazidime $(30 \mu \mathrm{g})$ & $\begin{array}{l}\text { Sensitive } \\
\text { Resistant }\end{array}$ & $\begin{array}{l}24(63.15 \%) \\
14(36.84 \%)\end{array}$ \\
\hline Piperacillin $(100 \mu g)$ & $\begin{array}{l}\text { Sensitive } \\
\text { Resistant }\end{array}$ & $\begin{array}{l}24(63.15 \%) \\
14(36.84 \%)\end{array}$ \\
\hline Gentamicin $(10 \mu \mathrm{g})$ & $\begin{array}{l}\text { Sensitive } \\
\text { Resistant }\end{array}$ & $\begin{array}{l}24(63.15 \%) \\
14(36.84 \%)\end{array}$ \\
\hline Netilmicin $(30 \mu \mathrm{g})$ & $\begin{array}{l}\text { Sensitive } \\
\text { Resistant }\end{array}$ & $\begin{array}{l}24(63.15 \%) \\
14(36.84 \%)\end{array}$ \\
\hline Tobramycin $(10 \mu g)$ & $\begin{array}{l}\text { Sensitive } \\
\text { Resistant }\end{array}$ & $\begin{array}{l}24(63.15 \%) \\
14(36.84 \%)\end{array}$ \\
\hline Amikacin $(30 \mu \mathrm{g})$ & $\begin{array}{l}\text { Sensitive } \\
\text { Resistant }\end{array}$ & $\begin{array}{l}32(84.21 \%) \\
6(15.78 \%)\end{array}$ \\
\hline 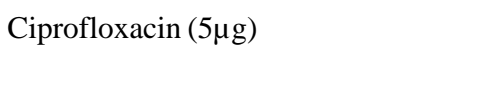 & $\begin{array}{l}\text { Sensitive } \\
\text { Resistant }\end{array}$ & $\begin{array}{l}19(50 \%) \\
19(50 \%)\end{array}$ \\
\hline Aztreonam $(30 \mu \mathrm{g})$ & $\begin{array}{l}\text { Sensitive } \\
\text { Resistant }\end{array}$ & $\begin{array}{l}24(63.15) \\
14(36.84 \%)\end{array}$ \\
\hline Cefepime $(30 \mu g)$ & $\begin{array}{l}\text { Sensitive } \\
\text { Resistant }\end{array}$ & $\begin{array}{l}24(63.15 \%) \\
14(36.84 \%)\end{array}$ \\
\hline Cefoperazone - Salbactum $(75 / 30 \mu g)$ & $\begin{array}{l}\text { Sensitive } \\
\text { Resistant }\end{array}$ & $\begin{array}{l}19(50 \%) \\
19(50 \%)\end{array}$ \\
\hline 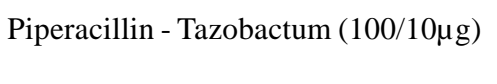 & $\begin{array}{l}\text { Sensitive } \\
\text { Resistant }\end{array}$ & $\begin{array}{l}24(63.15 \%) \\
14(36.84 \%)\end{array}$ \\
\hline Ticarcillin - Clavulanic acid (75/10 $\mu \mathrm{g})$ & $\begin{array}{l}\text { Sensitive } \\
\text { Resistant }\end{array}$ & $\begin{array}{l}24(63.15 \%) \\
14(36.84 \%)\end{array}$ \\
\hline Meropenem $(10 \mu \mathrm{g})$ & $\begin{array}{l}\text { Sensitive } \\
\text { Resistant }\end{array}$ & $\begin{array}{l}38(100 \%) \\
0(0 \%)\end{array}$ \\
\hline
\end{tabular}


J.B. Sherchan et al.Multi-Drug Resistant.......

Table 3. Antibiotic sensitivity pattern of E. coli, K. pneumonia and A. baumanni

\begin{tabular}{|c|c|c|c|c|}
\hline ANTIBIOTICS & & $\begin{array}{c}\text { Escherichia coli } \\
(\mathrm{N}=9)\end{array}$ & $\begin{array}{c}\text { Klebsiella } \\
\text { pneumoniae } \\
(\mathrm{N}=22)\end{array}$ & $\begin{array}{c}\text { Acinetobacter } \\
\text { baumannii } \\
(\mathrm{N}=\mathbf{3 0})\end{array}$ \\
\hline 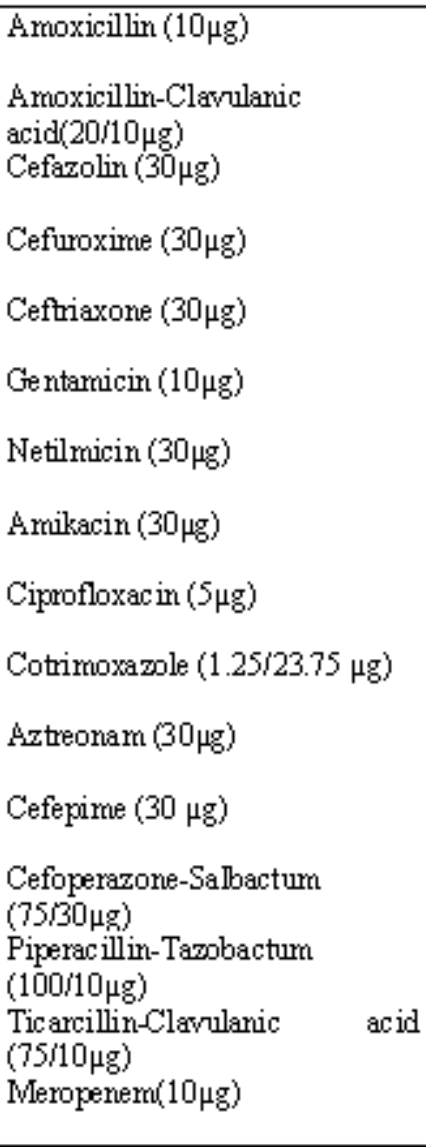 & $\begin{array}{l}\text { Sersitive } \\
\text { Resistant } \\
\text { Sensitive } \\
\text { Resistant } \\
\text { Sersitive } \\
\text { Resistant } \\
\text { Sersitive } \\
\text { Resistant } \\
\text { Sersitive } \\
\text { Resistant } \\
\text { Sensitive } \\
\text { Resistant } \\
\text { Sersitive } \\
\text { Resistant } \\
\text { Sensitive } \\
\text { Resistant } \\
\text { Sersitive } \\
\text { Resistant } \\
\text { Sensitive } \\
\text { Resistant } \\
\text { Sersitive } \\
\text { Resistant } \\
\text { Sensitive } \\
\text { Resistant } \\
\text { Sersitive } \\
\text { Resistant } \\
\text { Sensitive } \\
\text { Resistant } \\
\text { Sersitive } \\
\text { Resistant } \\
\text { Sensitive } \\
\text { Resistant }\end{array}$ & $\begin{array}{l}6(66.66 \%) \\
3(33.33 \%) \\
6(66.66 \%) \\
3(33.33 \%) \\
6(66.66 \%) \\
3(33.33 \%) \\
6(66.66 \%) \\
3(33.33 \%) \\
6(66.66 \%) \\
3(33.33 \%) \\
3(33.33 \%) \\
6(66.66 \%) \\
3(33.33 \%) \\
6(66.66 \%) \\
8(88.88 \%) \\
1(11.11 \%) \\
2(22.22 \%) \\
7(77.78 \%) \\
4(44.44 \%) \\
5(55.56 \%) \\
6(66.66 \%) \\
3(33.33 \%) \\
9(100 \%) \\
0(0 \%) \\
6(66.66 \%) \\
3(33.33 \%) \\
6(66.66 \%) \\
3(33.33 \%) \\
6(66.66 \%) \\
3(33.33 \%) \\
9(100 \%) \\
0(0 \%)\end{array}$ & 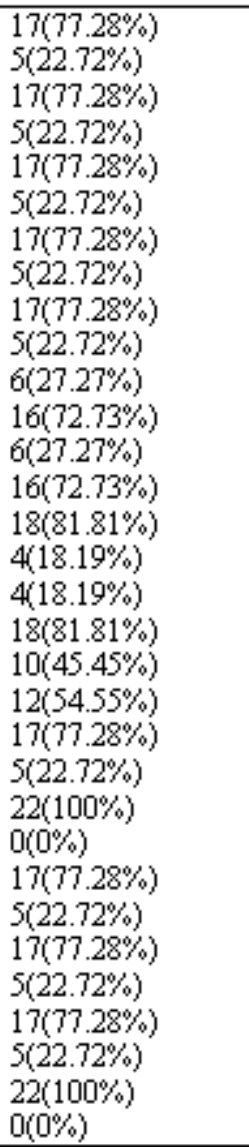 & 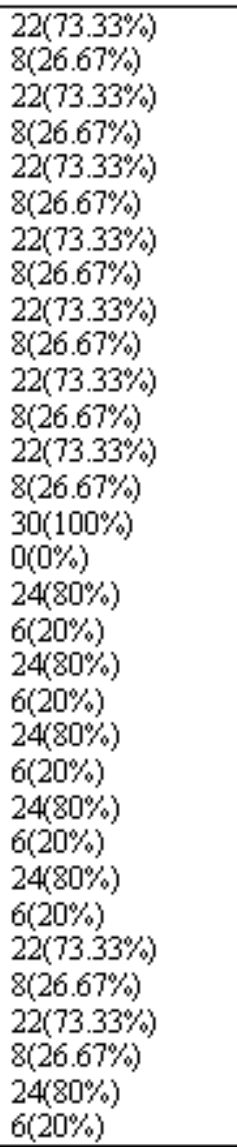 \\
\hline
\end{tabular}

Of the total isolates in the study, gram negative bacteria was significantly high (94.28\%) compared to gram positive bacterial isolates $(5.72 \%)(\mathrm{P}<0.05)$. The most common isolates found were $P$. aeruginosa among the total monomicrobial isolates. $P$. aeruginosa was the predominant organism causing community acquired LRTI in a study by Francisco Arancibia et al., (Francisco Arancibia 2002) in Spain, which correlates with our study.

Among the bacterial isolates higher percentage of MDR strains belonged to $S$. aureus $(50 \%, 3)$ followed by $P$. aeruginosa $(36.84 \%, 14)$, E. coli $(33.33 \%, 3), A$. baumannii $(26.66 \%$, 8) and K. pneumonia $(22.72 \%, 5)$. Hence total 33 (31.43\%) out of 105 monomicrobial isolate were MDR. All MDR E. coli, Klebsiella spp, Pseudomonas were ESBL producers. ESBL production is coded by genes that are prevalently located on large conjugative plasmids of 80-160 kb in size (Subha 2002).

$(20 \%, 6)$ out of total A. baumannii isolated produced MBL and was not found to produce ESBL during the study. All MDR S. aureus isolates were found to be resistant to methicillin.

Carbapenems, Cefepime were found to be the most effective antibiotic for E. coli and K. pneumonia. Amikacin was found to be effective for A. baumanni which produced metallo-betalactamase. Acinetobacter pneumonia has been more common in critically ill 
patients in Asia ranging from 4-44\% and European health care centre 0 - 35\%, however it is low in United states Health care centre ( 6-11\%) (Falagas 2008). In the last few years, resistance to antibacterial drugs has been increasing in Acinetobacter spp which will likely become a substantial treatment challenge in the future (Gaynes 2005). Carbapenems have potent activity against multidrug resistant Acinetobacter isolates. Acinetobacter may develop resistance to carbapenem through various mechanisms including class B and D carbapenemase production, decreased permeability, altered penicillin binding proteins and rarely over expression of efflux pumps (Heritier 2005, Quale 2003).

Carbapenems are used as the last resort for the treatment of MDR gram negative bacterial infection. However, since last 15 years, acquired resistance to this life saving antimicrobial has been increasingly reported not only in Pseudomonas and Acinetobacter spp (Gupta 2006), but also among members of Enterobacteriaceae. This resistance is mainly mediated by MBLs. Carbapenem group of antibiotics play a vital role in the management of gram negative infection, because of their broad spectrum activity and stability to hydrolysis by most of the â-lactamase including extended spectrum â-lactamases (ESBL). Carbapenem resistant Acinetobacter spp due to metallo â-lactamas (MBLs) production have been reported from different places (Ohara 2007, Peleg 2005, Oh 2003). The emergence of these MBLs in gram negative bacilli is becoming a therapeutic challenge as these enzymes possess high hydrolytic activity that leads to degradation of higher generation cephalosporins. Moreover, the treatment alternatives are unavailable or expensive/ toxic with poor outcome (Marra 2006). Plasmid mediated MBL genes spread rapidly to other species of gram negative bacilli (Ikonomidis 2005). So it is important that the rapid detection of metallo â- lactamase production is necessary to change the effective treatment to maximize the prevention from such infection in the health care institution. Vancomycin, Teicoplanin and Linezolid were found to be the most effective antibiotics for MRSA.

Out of total 33 MDR bacterial possessing patients 10 people were diabetic, 8 patients' age was over 75 years, 5 had malignancy, and 5 patients had renal impairment. Hence 28 out of 33 MDR isolate possessing patients had comorbid illness, i.e., $84.8 \%$ of MDR isolate possessing patients had comorbid illness and risk factors.

\section{Acknowledgements}

We would like to thank all the staff of Dirgh-Jeevan Health Care and Research Centre for their help and cooperation. The study received logistic support from National Center for Global Health and Medicine, Tokyo, Japan.

\section{Reference}

File, T.M. 2000. The epidemiology of respiratory tract infection. Semin Respir Infect. 15:184-194.

Rossolini, G.M., J.D. Docquier. 2005. Metallo- betalactamases: a last frontier fro beta- lactams $15^{\text {th }}$ European Congress of Clinical Microbiology and Infectious Diseases, Copenhegen/ Denmark.

Araj, G.F. and J.N. Samaha- Kfoury. 2003. Recent developments in beta- lactamases and extended spectrum beta lactamases. BMJ. 327:1209-1213.

Clinical and Laboratory Standards Institute. 2007. Performance standards for antimicrobial susceptibility testing, $17^{\text {th }}$ informational supplement. Wayne, PA: CLSI.; M100-S17.

Francisco Arancibia et al. 2002. Community-Acquired Pneumonia Due to Gram- negative Bacteria and Pseudomonas aeruginosa: Title and subTitle BreakIncidence, Risk, and Prognosis. Arch Intern Med. 162:1849-1858.

Subha, A., S. Ananthan. 2002. ESBL mediated resistance to third generation cephalosporins among $K$. pneumoniae in Chhenai. Ind J Med Microbiol. 20:92-95.

Falagas, M.E., E.A. Karveli. 2008. EA, Siempos II, Vardakas KZ. Acinetobacter infections: a growing threat for critically ill patients. Epidemiol Infect. 136:1009-1019.

Gaynes, R., J.R. Edwards et al. 2005. National Nosocomial Infections Surveillance System. Overview of nosocomial infections caused by gram negative bacilli. J Clin Infect Dis. 41:848-854.

Heritier, C, L. Poirel, T. Lambert, P. Nordmann. 2005. Contribution of acquired carbapenem hydrolyzing oxacillinase to carbapenem resistance in A. baumannii. J Antimicrob Agents Chemother 49:3198-3202.

Quale, J, S. Bratu, D. Landman, R. Heddurshetti. 2003. Molecular epidemiology and mechanism of carbapenem resistance in Acinetobacter baumannii endemic in New York City. J Clin Infect Dis. 37:214-220.

Gupta, V., P. Datta. J. 2006. Chander. Prevalence of metallobeta- lactamase producing Pseudomonas spp and Acinetobacter spp in a tertiary care hospital in India. J Infect 52:311-314. 


\section{J.B. Sherchan et al./Multi-Drug Resistant.......}

Ohara, M, S. Kouda,M. Onodera, Y. Fujiiue, M. Sasaki, T. Kohara et al. 2007. Molecular characterization of imienem resistant Pseudomonas aeruginosa in Hiroshima, Japan. Microbiol Immunol . 51:271-277

Peleg. A.Y., C. Franlin, J.M. Bell, D.W. Spelman. 2005. Dissemination of metallo- beta -lactamase gene bla IMP4 among gram negative pathogens in a clinical setting in Australia. Clin Infect Dis. 41:1549-1556.

Oh, E.J., S. Lee, Y.J. Park, J.J. Park, K. Park, S.I. Kim, et. al. 2003. Prevalence of metallo- beta- lactamase among Pseudomonas aeruginosa and Acinetobacter baumannii in a Korean university hospital and comparison of screening methods for detecting metallo- beta- lactamase. J Microbiol Methods 54:411-418

Marra, A.R., C.A. Pereira, A.C. Gales, L.C. Menezes, R.G. Cal, J.M. de Souza et. al. 2006. Blood stream infections with metallo -beta- lactamase producing Pseudomonas aeruginosa: Epidemiology, microbiology and clinical outcomes. Antimicrob Agents Chenother 50:388-390.

Ikonomidis, A, D. Tokatlidou, I. Kristo, D. Sofianou, A. Tsakris, P. Mantzana et. al. 2005. Outbreak in distinct regions due to a single Klebsiella pneumoniae clone carrying a bla VIM 1 metallo- beta- lactamase gene. $J$ Clin Microbiol. 43:5344-5347. 
Nepal Journal of Science and Technology Vol. 13, No. 1 (2012) 